\title{
Effectiveness of Bromelain and Papain Enzymes in Hatching Media with Different Salinity on the Hatching Success of Tilapia (Oreochromis niloticus) Eggs
}

\author{
Fani Fariedah ${ }^{1 *}$, Maheno Sri Widodo ${ }^{1}$ and Soko Nuswantoro ${ }^{1}$ \\ ${ }^{1}$ Aquaculture Study Program, Department of Fisheries Resources Utilization, Universitas Brawijaya, \\ Veteran St., Ketawanggede, Lowokwaru, Malang, East Java 65145, Indonesia
}

*Correspondence :

fanifariedah@ub.ac.id

Received : 2020-10-11

Accepted : 2020-12-03

Keywords :

Bromelain, Papain, Salinity

\begin{abstract}
Tilapia is euryhaline fish that is commonly cultivated in former shrimp ponds and belongs to mouth breeders. The purpose of this study was to determine the hatching success of Tilapia eggs outside the mother's mouth, which was carried out in the salinity medium added with bromelain and papain enzymes. The research method was factorial CRD with an enzyme (factor A) and salinity (factor B), with three replications. The research was conducted at the Fish Cultivation laboratory of the Faculty of Fisheries and Marine Sciences, Brawijaya University in January-February 2020. The results showed that papain had more effect on hatchability (93.77\%), while the salinity of 5 ppt was the salinity that produced the highest hatchability (93.89\%). Moreover, the hatchability was also influenced by the interaction between the enzyme and salinity, namely papain enzyme with a salinity of 5 ppt (98.89\%). Meanwhile, bromelain had more effect on the survival of larvae $(87.86 \%)$, and the salinity that produced the highest survival rate was at 5 ppt $(85.75 \%)$, but the interaction between enzyme and salinity did not have an effect on the survival of larvae.
\end{abstract}

\section{INTRODUCTION}

Tilapia is an alternative commodity that can be cultivated on land that was formerly used for shrimp ponds. Tilapia has euryhaline properties or can live and grow over a wide salinity range. Tilapia maintenance has a low risk and low operating costs. Tilapia export demand is increasing, proven by the increasing number of tilapia fish production from year to year. The Ministry of Marine Affairs and Fisheries reported that tilapia production in 2013 increased to 914.78 thousand tons, 999.69 thousand tons in 2014, and 1,084 million tons in 2015 (Putra et al., 2018). The increase in tilapia production still requires continuous development to achieve the production target.

The main problem that often arises in the cultivation of tilapia in brackish water/pond environments is seeds. The distribution of tilapia seeds must be adapted first as the adaptation process takes a long time. Djunaedi et al. (2016) stated that the adaptation process of tilapia seeds should be carried out gradually by adding seawater to the reservoir gradually until it reaches $5 \mathrm{ppt}$ every week. However, this is less efficient in time because it takes a long time. 
The method that can be done to shorten the adaptation time is to hatch tilapia eggs in the salinity medium. Watanabe et al. (1985) stated that the salinity medium could be used to hatch Tilapia eggs. Furthermore, it is stated that the survival rate of Tilapia eggs spawned in fresh water and hatched on media with a salinity of 0,5 , and $10 \mathrm{ppt}$ has an average of $>80 \%$.

Salinity affects water absorption, osmotic work rate, and the hardening process of the chorion membrane in eggs. This phenomenon is also thought to affect embryo growth and osmoregulation through the energy utilization of egg yolk (Heltonika, 2014). Another factor that can affect the egg hatching process besides salinity is the protease enzyme.

Protease can dissolve the egg wall so that the embryo will be easy to come out (Djarijah, 2001). The bromelin papain enzyme is one of the protease enzymes. Bromelain is found in the plant family Bromeliaceae on leaves, stems, and fruits. Salahudin (2011) stated that Bromelin is included in the extracellular protease enzyme which is capable of hydrolyzing protein into simpler compounds such as short-chain peptides and amino acids. Papain can be obtained from papaya fruit and papaya sap. Papain, like bromelain, contains quite a lot of proteolytic enzymes (protein decomposers). This enzyme is used for the complete breakdown of peptide bonds in proteins so that proteins break down into simpler peptide bonds (Amalia et al., 2013). In previous studies, it is suggested that giving the bromelain enzyme of 0.1223 micromoles and papain of 0.146 micromoles in the hatching of tilapia affected the hatchability of tilapia eggs.

This study combines the work of the bromelain and papain enzymes with salinity in hatching media. This research is expected to be able to help incubate Tilapia eggs outside the mother's body so that it will accelerate the recovery period of the mother after spawning and in the end be able to provide continuous tilapia seeds.

\section{METHODOLOGY}

\section{Place and Time}

The research was conducted from January to March 2020 at the Fish Cultivation Laboratory, Faculty of Fisheries and Marine Sciences, Brawijaya University.

\section{Research Material}

The materials used in this study were: 6-month-old tilapia broodstock, tilapia fish eggs, detergent and foam, papain, bromelain, black plastic bags, freshwater, distilled water, glue, and label paper.

The tools used for this research included: a microscope, aquarium, aerator, T-pipe, L-pipe, hose, clear plastic bottle, roll cable, $\mathrm{pH}$ pen, $\mathrm{Hg}$ thermometer, DO meter, hand tally counter, syringe, drop pipette, water pump, shelf, camera, hapa, film bottle, jar, and heater.

\section{Research Design}

Based on the results of previous studies stating that the best hatchability was using bromelain enzyme of 0.1223 micromoles and papain enzyme of 0.146 micromoles, this study used a factorial randomized design with the main factors of bromelain enzyme and papain enzyme as factor $\mathrm{A}$ and salinity treatment $(0 ; 2.5$; 5; 7.5; and $10 \mathrm{ppt)}$ as a factor $B$ with three replications.

\section{Work Procedures}

Research preparation began with preparing and cleaning the research media. The research media were in the form of a $10 \mathrm{~L}$ jar and an incubator. The jar was washed using detergent and then dried for 24 hours.

\section{The Making of Hatching Incubation}

Tilapia egg hatching used a hatching incubator. Tilapia egg hatching incubator itself was made from 2 bottles of 1.5L mineral water combined into one. A pipe was given in the middle section with a 
length of $30 \mathrm{~cm}$ and $1.5 \mathrm{~cm}$ meters. The pipe in the middle of the incubator was connected to a pump so that water from the jar could flow into the incubator. Thus, the water recirculation process could occur in the two containers, between the water in the incubation container and the water in the jar.

\section{Media Preparation}

The media used in this study was clean freshwater that had been deposited for 24 hours. The sedimentation process was carried out to remove parasites in the water. After being deposited, the water was given treatment in the form of a commercial bromelain enzyme which aimed to accelerate the hatching time of the eggs.

\section{Preparation of Test Samples}

The samples were obtained from the mouth of the tilapia that had spawned. The steps taken in taking tilapia eggs were as follows: tilapia that had spawned in the pool were examined. After it was found that fish were doing mouthbrooding, the level of the water pond was reduced. The fish incubating the eggs were taken, then the eggs were removed through their mouths and put into experimental units

\section{Parameters}

One of the main parameters is the successful hatching of eggs in tilapia (Oreochromis niloticus). Hatchability of eggs is the percentage of eggs that hatch after the eggs are fertilized. According to Effendi et al. (2012), the hatching rate is the percentage of the degree of eggs hatching that can be known and calculated using a formula, namely:

$$
\mathrm{HR}(\%)=\frac{\text { number of hatching eggs }}{\text { total number of eggs }} 100 \%
$$

The survival rate is the percentage of the number of live fish at the end of the study compared to the number of fish at the beginning of stocking. The observation of the survival rate in this study was carried out after the yolk of the tilapia larvae had run out. The calculation of survival rate can be done using the formula:

$\mathrm{SR}(\%)=\frac{\mathrm{Nt}}{\mathrm{No}} \times 100 \%$

Note:

$\mathrm{SR}=$ Survival Rate (\%)

$\mathrm{Nt}=$ Number of live seeds at the end of study

No $=$ Number of live seeds at the beginning of the study

\section{Data Analysis}

Data were analyzed using the twoway ANOVA test. If it showed a significant or very significant effect, it was followed by the Tukey's Honestly Significant Difference (HSD) test or Least Significant Difference (LSD) test, which was also conducted to see if there was an interaction of the two factors given

\section{RESULTS AND DISCUSSION Hatchability of Tilapia Eggs}

The results of observations made on eggs that were hatched on salinity medium with the addition of bromelain and papain enzymes showed that the higher the salinity, the higher the hatchability, but the hatchability started decreasing when given salinity higher than a combination of 5 ppt salinity with the addition of the papain enzyme at $98.89+42.01$, which was also noted as the highest hatchability. The hatchability percentage of tilapia fish eggs is presented in Table 1. 
Table 1. The percentage of hatchability of tilapia eggs on salinity medium with the addition of bromelain and papain enzymes.

\begin{tabular}{clcccc}
\hline \multicolumn{2}{c}{ Factor } & \multicolumn{3}{c}{ Repetition (\%) } & \multirow{2}{*}{ Average } \\
\cline { 1 - 5 } Enzyme & \multicolumn{1}{c}{ Salinity } & 1 & 2 & 3 & \\
\hline & $1(0 \mathrm{ppt})$ & 66.67 & 66.67 & 70 & $67.78 \pm 1.92$ \\
Bromelain & $2(2.5 \mathrm{ppt})$ & 66.67 & 76.67 & 66.67 & $70.00 \pm 5.77$ \\
(A) & $3(5 \mathrm{ppt})$ & 86.67 & 86.67 & 93.33 & $88.89 \pm 3.85$ \\
& $4(7.5 \mathrm{ppt})$ & 86.67 & 90 & 83.33 & $86.67 \pm 3.33$ \\
& $5(10 \mathrm{ppt})$ & 70 & 76.67 & 66.67 & $71.11 \pm 5.09$ \\
& $1(0 \mathrm{ppt})$ & 93.33 & 93.33 & 90 & $92.22 \pm 41.26$ \\
Papain & $2(2.5 \mathrm{ppt})$ & 90 & 96.67 & 96.67 & $94.44 \pm 41.21$ \\
(B) & $3(5 \mathrm{ppt})$ & 100 & 96.67 & 100 & $98.89 \pm 42.01$ \\
& $4(7.5 \mathrm{ppt})$ & 90 & 96.67 & 9.33 & $93.33 \pm 38.46$ \\
& 5 (10 ppt) & 90 & 90 & 90 & $90 \pm 35.78$ \\
\hline
\end{tabular}

Table 1 shows that the highest hatchability of eggs was found in the medium with a salinity of 5 ppt and the addition of the papain enzyme in it. In general, the hatchability of tilapia eggs was higher in medium added with papain enzyme, with the lowest hatchability was in the medium with a salinity of 10 ppt. The highest hatchability in the medium added with bromelain enzyme was noted in the medium with a salinity of $5 \mathrm{ppt}$, while the lowest was in the medium with a salinity of $0 \mathrm{ppt}$.

The effect of salinity with the addition of the bromelain and papain enzymes on hatchability was then analyzed using the variance test. The results of the variance test showed that the enzyme factor had a p-value $<0.05$, so there was a significant difference between the use of the bromelain and papain enzymes on hatchability. The salinity factor had a p-value $<0.05$, so there was a minimum of 1 salinity which gave a significantly different result on hatchability. Moreover, the enzyme and salinity interaction factor had a p-value $<0.05$, so there was at least one difference between treatments on the interaction of enzymes and salinity on hatchability.

Based on these results, further testing in the form of the enzyme factor and the salinity factor was conducted. Before further testing, it is necessary to calculate the $\mathrm{CV}$ :

$$
\begin{aligned}
& \mathrm{KK}= \frac{\sqrt{\mathrm{KTG}}}{\underline{\mathrm{x}}}=\frac{\sqrt{12.22}}{85.33} \times 100 \%=4.10 \% \\
& \text { Coefficient of Variation }(\mathrm{KK}) \text { was }
\end{aligned}
$$
classified as moderate so that the followup test used was the Honestly Significant Difference Test (HSD). The results of the further test using HSD are shown in Table 2.

Table 2. Results of the HSD Test (enzyme).

\begin{tabular}{cccll}
\hline Enzyme & N & Mean & Grouping & \\
\hline B & 15 & 93.7780 & A & \\
A & 15 & 76.8907 & & B \\
\hline
\end{tabular}

Note: $\quad$ Means that do not share a letter are significantly different.

Based on the results of the HSD test (Table 2) above, it can be seen that the use of $B$ (papain enzyme) provided better hatchability results than the use of $A$ (bromelain enzyme). This is likely because the papain enzyme works by destroying the mucopolysaccharide layer first, then quickly converting it into an amorphous mass. During this process, the myofibrils and collagen will undergo hydrolysis, causing the bonds between muscles to disappear and become shorter fragments (Lawrie, 2003). With this mechanism of action, the papain enzyme is thought to be able to damage the chorion layer so that the larvae in the eggs will hatch. Slightly 
different from the bromelain enzyme, the bromelain enzyme acts on protein tissue and hydrolyzes it.

The protein hydrolysis process by the means of the bromelain enzyme could run faster than by the means of the papain enzyme. As stated by Okfrianti et al.
(2011) that for beef tenderization by the bromelain enzyme, the results are better and faster than by the papain enzyme. Furthermore, the LSD test was carried out on salinity, and the results can be seen in Table 3.

Table 3. Results of the HSD Test (salinity).

Note: $\quad$ Means that do not share a letter are significantly different.

\begin{tabular}{lllll}
\hline Salinity (ppt) & & Mean & Grouping & \\
\hline 5.0 & & 93,8900 & A & \\
7.5 & 1 & 90,0000 & A & \\
2.5 & $\quad$ & 82,2250 & & B \\
10.0 & 1 & 80,5567 & & B \\
0.0 & & & B \\
\hline
\end{tabular}

Based on the results of the HSD test (Table 3) above, it can be seen that the use of salinity of 5 and 7.5 ppt gave the best dripping power than the others. The low hatchability at 0 salinity was due to the appearance of molds on the eggs. The fine threads that were formed due to the fungi covered the entire surface of the egg, causing the egg to not be able to get oxygen for metabolism and eventually die. Lingga et al. (2012) stated that the chorion layer in the egg can be penetrated by mold spores, which then develop and carry out the reproductive process so that the nutrients in the egg will be absorbed.

The high rate of hatchability at salinity 5 and 7.5 was due to the salinity was suitable with the conditions expected for the development of fish eggs. This salinity is said to be isoosmotic so the eggs do not waste much energy to osmoregulate the ion balance between inside and outside the egg, and consequently, the energy they have will be used for embryo development. Fujaya (2008) stated that an isosmotic state is a similar condition between the concentration of body fluids (eggs) and the concentration of the media. Also, at a salinity of 5 and $7.5 \mathrm{ppt}$, there was no fungal infection in eggs. These results are different from those presented by Darwisito et al. (2015), which stated that the optimal salinity for hatching tilapia eggs without bromelain enzyme is $10 \mathrm{ppt}$.

To determine the interaction between the enzyme factor and salinity, the HSD test was carried, as shown in Table 4.

Table 4. Results of the HSD Test (interaction between enzyme and salinity).

\begin{tabular}{|c|c|c|c|c|c|}
\hline Enzyme*Salinity & ] & Mean & \multicolumn{3}{|c|}{ Grouping } \\
\hline B 5.0 & : & 98,8900 & $\mathrm{~A}$ & & \\
\hline B 2.5 & : & 94,4467 & A & B & \\
\hline B 7.5 & : & 93,3333 & A & B & \\
\hline В 0.0 & $:$ & 92,2200 & A & B & \\
\hline В 10.0 & : & 90,0000 & $\mathrm{~A}$ & B & \\
\hline A 5.0 & : & 88,8900 & $\mathrm{~A}$ & B & \\
\hline A 7.5 & $:$ & 86,6667 & & B & \\
\hline A 10.0 & : & 71,1133 & & & C \\
\hline A 2.5 & : & 70,0033 & & & C \\
\hline A 0.0 & : & 67,7800 & & & $\mathrm{C}$ \\
\hline
\end{tabular}


Based on the results of the HSD test above, it can be seen that the use of enzyme B (papain) with a salinity of 5 , 2.5, 7.5, 0, and $10 \mathrm{ppt}$ and enzyme A (bromelin) with a salinity of 5 ppt gave the best hatchability than others.

\section{Survival Rate}

Results of observations made on eggs reared on the salinity medium with the addition of bromelain and papain enzymes showed that the higher the salinity, the higher the survival rate, but the survival rate decreased when given salinity higher than a combination of $5 \mathrm{ppt}$ salinity with the addition of the enzyme bromelain at $95.15+5.53$, which was also noted as the highest survival rate. The percentage of the survival rate is presented in Table 5.

Table 5. Percentage of survival of tilapia eggs on the salinity medium with the addition of the bromelain and papain enzymes.

\begin{tabular}{|c|c|c|c|c|c|}
\hline \multicolumn{2}{|l|}{ Factor } & \multicolumn{3}{|c|}{ Repetition (\%) } & \multirow{2}{*}{ Mean } \\
\hline Enzyme & Salinity & 1 & 2 & 3 & \\
\hline \multirow{5}{*}{ Bromelain (A) } & 1 (0 ppt) & 85 & 95 & 85.71 & $88.57 \pm 5.58$ \\
\hline & $2(2.5 \mathrm{ppt})$ & 90 & 95.65 & 90 & $91.88 \pm 3.26$ \\
\hline & 3 (5 ppt) & 96.15 & 100 & 89.29 & $95.15 \underline{ \pm} 5.53$ \\
\hline & 4 (7.5 ppt) & 88.46 & 88.89 & 84 & $87.12 \pm 2.71$ \\
\hline & 5 (10 ppt) & 80.95 & 73.91 & 75 & $76.62 \pm 3.79$ \\
\hline \multirow{5}{*}{ Papain (B) } & 1 (0 ppt) & 60.71 & 53.57 & 66.67 & $60.32 \pm 6.56$ \\
\hline & $2(2,5 \mathrm{ppt})$ & 62.96 & 62.07 & 44.83 & $64.75 \pm 10.22$ \\
\hline & 3 (5 ppt) & 73.33 & 72.41 & 83.33 & $76.36 \pm 6.06$ \\
\hline & $4(7,5 \mathrm{ppt})$ & 51.85 & 79.31 & 68.96 & $66.71 \pm 13.87$ \\
\hline & $5(10 \mathrm{ppt})$ & 51.85 & 59.26 & 62.96 & $58.02 \pm 5.66$ \\
\hline
\end{tabular}

The effect of salinity with the addition of bromelain and papain enzymes on the survival of tilapia larvae was then analyzed using an Analysis of Variance (ANOVA) test. The results of the ANOVA showed that the enzyme factor had a pvalue $<0.05$, so there was a significant difference between the use of the bromelain and papain enzymes on survival. The salinity factor had a p-value $<0.05$ so that there was at least 1 salinity which gave a significantly different result on survival. The enzyme and salinity interaction factor had a p-value $>0.05$, so there was no difference between treatments on the enzyme and salinity interactions.

Based on these results, what can be further tested was the enzyme factor and the salinity factor. Before further testing, it is necessary to calculate the Coefficient of Variation (CV):

$$
\mathrm{KK}=\frac{\sqrt{\mathrm{KTG}}}{\underline{\mathrm{x}}}=\frac{\sqrt{50.14}}{75.74} \times 100 \%=9.35 \%
$$

Coefficient of Variation (CV) was classified as moderate so that the followup test used was the LSD test. The results of the further test using LSD are as follows:

Table 6. Results of the LSD Test (enzyme).

\begin{tabular}{cclll}
\hline Enzyme & $\mathrm{N}$ & Mean & Grouping & \\
\hline $\mathrm{A}$ & 15 & 87.8673 & $\mathrm{~A}$ & \\
$\mathrm{~B}$ & 15 & 63.6047 & & $\mathrm{~B}$ \\
\hline
\end{tabular}

Note: $\quad$ Means that do not share a letter are significantly different.

Based on the results of the LSD test above, it can be seen that the use of A (bromelain enzyme) provided better survival results than the use of $B$ (papain enzyme). This was because the papain enzyme worked faster in the protein hydrolysis process compared to the bromelain enzyme, so when the larvae 
were still in the egg phase they had received the impact of the papain enzyme, which could cause damage to important organs of the larvae, so when they hatched these organs could not function properly and cause the death of the larvae. Furthermore, the HSD test was carried out on salinity, and the results are shown in Table 7.

Table 7. Results of the LSD Test (salinity).

\begin{tabular}{lllll}
\hline Salinity & Mean & Grouping & \\
\hline 5.0 & 85.7517 & A & & \\
7.5 & 76.9117 & & B & \\
0.0 & 74.4433 & & B & C \\
2.5 & 74.2517 & & B & C \\
10.0 & 67.3217 & & & C \\
\hline
\end{tabular}

Note: $\quad$ Means that do not share a letter are significantly different.

Based on the results of the LSD test above, it can be seen that the use of salinity of 5 gave the best survival than others. This was because at the salinity of $5 \mathrm{ppt}$ the fish larvae were in the isoosmotic state. The lowest survival rate was produced at a salinity of $10 \mathrm{ppt}$ because larvae would need more energy to osmoregulate or balance the ion concentration between inside and outside their body, so the energy that should be used for growth is reduced. This is in accordance with the statement of Rahim et al. (2015) stating that the seed mortality is higher in the higher salinity. Prakoso and Kurniawan (2015) stated that exposure to salinity exceeding the salinity tolerance limit causes larvae to have difficulty in maintaining their life due to the high difference in osmotic pressure between larvae and their environment. This is closely related to the chloride cells in fish which function as an osmoregulator that plays a role in tolerating salinity exposure in fish. Chloride cells will respond to high salinity exposure. Disturbance due to changes in salinity can cause differences in the duration of embryogenesis, increase the likelihood of larval abnormalities, reduce hatching rates, and reduce the survival rates of larvae.

\section{CONCLUSION}

From the results of this study, it can be concluded that the papain enzyme produced better hatchability when compared to the bromelain enzyme, while the highest survival was obtained in the medium containing the bromelain enzyme. The optimal salinity that could be used as a medium was 5 ppt.

In hatchability, the interaction between enzymes and salinity had a very different effect, namely in the interaction between the papain enzyme and salinity of 5 ppt. Meanwhile, on survival, the interaction between enzymes and salinity did not have a significant effect.

\section{ACKNOWLEDGMENT}

Gratitude is expressed to the Faculty of Fisheries and Marine Sciences, fellow lecturers, students and all parties who have helped the accomplishment of this research.

\section{REFERENCES}

Amalia, R., Subandiyono and Arini, E., 2013. Pengaruh penggunaan papain terhadap tingkat pemanfaatan protein pakan dan pertumbuhan lele dumbo (Clarias gariepinus). Journal of aquaculture management and technology, 2(1), pp.136-143. https: //ejournal3.undip.ac.id/index.php/ jamt/article/view/2086

Darwisito, S., Sinjal, H.J.and Wahyuni, I., 2015. Tingkat perkembangan gonad, kualitas telur dan ketahanan hidup larva ikan nila (Oreochromis niloticus) berdasarkan perbedaan salinitas. Jurnal LPPM bidang sains 
dan teknologi, 2(2), pp.86-94. https://ejournal.unsrat.ac.id/index. php/lppmsains/article/download/1 0695/10283

Djarijah, A.S., 2001. Pembenihan ikan mas. Kanisius. Yogyakarta. 89 p.

Djunaedi, A., Pribadi, R., Hartati, R., Redjeki, S., Astuti, R.W. and Septiarani, B., 2016. Pertumbuhan ikan nila larasasti (Oreochromis niloticus) di tambak dengan pemberian ransum pakan dan padat penebaran yang berbeda. Jurnal Kelautan Tropis, 19(2), pp. 131-142. https://doi.org/10.14710/jkt.v19i2 .840

Effendi, A.M., Pratjojo, W. and Sumarni, W., 2012. Optimalisasi penggunakaan enzim bromelin dari sari bonggol nanas dalam pembuatan minyak kelapa. Indonesiana journal of chemical science, 1(1), pp.1-6. https://journal .unnes.ac.id/sju/index.php/ijcs/arti cle/view/573

Fujaya, Y., 2008. Fisiologi ikan: Dasar pengembangan teknik perikanan. Rinneka Cipta. Jakarta. 179 p.

Heltonika, B., 2014. Pengaruh salinitas terhadap penetasan telur ikan jambal siam (Pangasius hypohthalmus). Jurnal akuakultur rawa Indonesia, 2(1), pp.13-23. https://doi.org/10.36706/jari.v2i1. 1959

Lawrie, R.A., 2003. Meat Science $5^{\text {th }}$ edition. UI press. Jakarta.

Lingga, M.N., Rustikawati, I. and Buwono, I.D., 2012. Efektifitas ekstrak bunga kecombrang (Nicolaia speciosa Horan) untuk pencegahan serangan Saprolegnia sp. pada lele sangkuriang. Jurnal perikanan dan kelautan, 3(4), pp.75-80. http://jur nal.unpad.ac.id/jpk/article/view/2 547

Okfrianti, Y., Kamsiah and Fitryani, Y., 2011. Pengaruh penambahan enzim protease tanaman terhadap sifat fisik dan organoleptik daging sapi. Jurnal sain peternakan Indonesia,
6(2), pp.125-135. https://doi.org/1 0.31186/jspi.id.6.2.125-136

Prakoso, V.A. and Kurniawan, 2015. Pengaruh stressor suhu dan salinitas terhadap perkembangan embrio ikan nilem (Osteochilus hasselti). Jurnal sains natural, 5(1), pp.49-59. https://doi.org/10.31938/jsn.v5i1. 99

Putra, E.M., G. Mahasri, and L.A. Sari., 2018. Infestasi ektoparasit pada ikan nila (Oreochromis niloticus) yang dipelihara dengan menggunakan sistem akuaponik dan tanpa akuaponik. Journal of aquaculture and fish health, 7(1), pp.42-49. http://dx.doi.org/10.204 73/jafh.v7i1.11242

Rahim, T., Tuiyo, R. and Hasim, 2015. Pengaruh salinitas berbeda terhadap pertumbuhan dan tingkat kelangsungan hidup benih ikan nila merah (Oreochromis niloticus) di Balai Benih Ikan Kota Gorontalo. NIKé Jurnal ilmiah perikanan dan kelautan, 3(1), pp.39-43. https://do i.org/10.37905/.v3i1.1315

Salahudin, F., 2011. The Effect of Settling Agent on Bromelain Enzyme Isolation from Pineapple Core. BIOPROPAL INDUSTRI, 2(1), pp. 2731. http://dx.doi.org/10.36974/jbi. v2i1.721

Watanabe, W.O., Kuo, C.M. and Huang, M.C., 1985. Salinity tolerance of nile tilapia fry (Oreochromis niloticus), spawned and hatched at various salinities. Aquaculture, 48(2), pp.159-176. https://doi.org/10.101 6/0044-8486(85)90102-4 